\title{
Herbicidal Activity of Penoxsulam And Bispyribac-Sodium and its Combination With Mineral Oil And Spreading Material on Weed Rice Plant
}

\author{
Marzouk, M. A.*, M. A. Abbassy*, Y. M. Ahmed**, S. M. Shebl*** and A. M. Khozimy* \\ * Department of Plant Protection, Faculty of Agriculture, Damanhour University. \\ ** Department of Plant Protection, Faculty of Agriculture, Suez Canal University. \\ *** Weed Research Program, Rice Research and Training Center, RRTC Sakha, Kafr El- Shiekh
}

Received: $20 / 1 / 2013$

\begin{abstract}
Two field experiments were carried out at the Experimental Farm of Rice Research and Training Center (RRTC), Sakha, Kafr El-sheikh, Egypt, during 2009 and 2010 rice growing seasons. to study the effect of certain postemergence herbicides (Penoxsulam and Bispyribac-sodium and their mixtures with mineral oil KZ and spreading material (Top film) on weeds control rice plant compared with non-chemical control Weedy check, The results The result showed that the number of tiller to Echinochloa crus-galli, Echinochloa colonum, Cyperus difformis. In all tested treatment from the results the most lesser above of weeds and highest percent reduction of weeds was found in penoxsulam and bispyribac-sodium at the recommended rate of each herbicides wean the half rate both compounds was compared one litter of spreading material or one litter of mineral oil was slightly increased of weeds with the higher increase of percent reduction in total weeds compared with the effect of the half rate only of each tested compound. penoxsulam $2.5 \%$ half rate $+1000 \mathrm{ml}$ spreading material which gives $82 \%, 87 \%, 83 \%$ and $84 \%, 92 \%, 88 \%$ during 2009 and 2010 season respectively. bispyribac-sodium $2 \%$ half rate $+1000 \mathrm{ml}$ spreading material which gives $89 \%, 89 \%, 89 \%$ and $88 \%, 94 \%, 87 \%$ reduction in the total number, Also gave the most highest percent reduction in total dry weight of weeds. When the mineral oil and spreading material were used with half recommended rate of the two above herbicides the percent reduction of dry weight of weed were approximately equal to the recommended rate of each tested herbicides such effect relieved to the efficacy of mineral oil and spreading material to improve the power of half rate to reach the effect of recommended rate.
\end{abstract}

Keywords: Weed- Rice- Benoxsulam- Bispyribac-sodium - Mineral oil- Spreading material - Echinochloa crus-galli, Echinochloa colonum, Cyperus difformis

\section{INTRODUCTION}

Rice, which is preferred food by most Egyptians, contributes about $20 \%$ of the per capita cereal consumption. Rice occupies about $22 \%$ of the cultivated area in Egypt during the summer season, thus consuming about $18 \%$ of total water resources. Rice is also one of the most effective and profitable mean of reclaiming hundreds of thousands feddans of saline lands (Wally, 1989). Moreover, rice is an important export crop in Egypt, and achieved high price in international markets. Weeds are among the most important yield-limiting constrains in Egyptian rice production, the major food crop of Egypt (Hassan, 2002). Weeds reduce the yield and quality of rice crop. It also raises the cost of production. In case of paddy, the yield drops by $15-20 \%$ percent and sometimes, even 50 percent. While in Egypt it resulted in yield losses ranged from 4.42 to $7.6 \mathrm{t}$ ha-1 with an average of 6.67 t/ha (75\%) (Hassan and Rao, 1994).Losses due to weeds have been reported in rice producing countries such as India, Philippines, while in the USA, yield and quality losses are estimated by about 15\% (De Datta 1980 and Smith et al., 1977). Direct seeding is linked to the use of herbicide, as without their use, weeds grow so rapidly in the stages before the fields can be flooded, that manual means of control are often not feasible, thiobencarb is a recommended herbicide for weed control in both transplanted and broadcast-seeded rice. It is reported as highly effective compound against C.difformis in addition to grassy weeds and active in flood water
(Taylor and Clampette, 2002). all the herbicidal treatments significantly reduced total weed density and dry weight over unweeded check. Among the treatments, post emergence application of bispyribacsodium $30 \mathrm{~g}$ ha-1 applied 15 at DAS (days after sowing) significantly reduced total weed density, dry weight and was on par with its higher doses of 40 and $50 \mathrm{~g}$ ha-1 with weed control efficiency of 74 to $79 \%$ (Rao and Ratnam, 2010). bispyribac- sodium suppressed weed count and dry weight by $80 \%$. Among non-chemical weed management strategies, sorghum residues scored over $50 \%$ reduction in weed density and dry weight. bispyribac- sodium with $3.51 \mathrm{t} / \mathrm{ha}^{-1}$ paddy yield appeared superior to penoxsulam (Abdul khaliq et al., 2011). The post- emergence application of bispyribacsodium was the most effective herbicide in reducing the total weed density and dry weight over the weedy check, followed by penoxsulam and pendimethalin, respectively. In conclusion, the post-emergence application of bispyribac-sodium can be used effectively to control weeds. (Jabran et al., 2012).

\section{MATERIAL AND METHODS}

Two field experiments were carried out at the Experimental Farm of Rice Research and Training Center (RRTC), Sakha, Kafr El-sheikh, Egypt, during 2009 and 2010 rice growing seasons. The study aimed to study the efficacy of certain herbicides in weed control, as well as their effect on growth, yield, and yield components of Rice (Oryza Sativa). Each 
experiment included fifteen chemical treatments (herbicides) beside one weedy check treatment as follows:

1- penoxsulam $2.5 \%$ (Renpo) at the rate of $400 \mathrm{ml} / \mathrm{fed}$ applied as post-emergence foliar spraying, 15 days after sowing.

2- penoxsulam $2.5 \%$ at the rate of $200 \mathrm{ml} / \mathrm{fed}$.

3- penoxsulam $2.5 \%$ at the rate of $200 \mathrm{ml} / \mathrm{fed}$ mixed with mineral oil (KZ oil) at the rate of $1000 \mathrm{ml} / \mathrm{fed}$.

4- penoxsulam at the rate of $200 \mathrm{ml} / \mathrm{fed}$ mixed with mineral oil (KZ oil) at the rate of $500 \mathrm{ml} / \mathrm{fed}$.

5- penoxsulam $2.5 \%$ at the rate of $200 \mathrm{ml} / \mathrm{fed}$ mixed with spreading materials (Top film) at the rate of $1000 \mathrm{ml} / \mathrm{fed}$.

6- penoxsulam $2.5 \%$ at the rate of $200 \mathrm{ml} / \mathrm{fed}$ mixed with spreading materials (Top film) at the rate of $500 \mathrm{ml} / \mathrm{fed}$.

7- bispyribac-sodium 2\% (Nominee) at the rate of 800 $\mathrm{ml} /$ fed applied as post-emergence foliar spraying, 20 days after sowing.

8 - bispyribac-sodium $2 \%$ at the rate of $400 \mathrm{ml} / \mathrm{fed}$.

9- bispyribac-sodium $2 \%$ at the rate of $400 \mathrm{ml} / \mathrm{fed}$ mixed with mineral oil (KZ oil) at the rate of 1000 $\mathrm{ml} / \mathrm{fed}$.

10- bispyribac-sodium $2 \%$ at the rate of $400 \mathrm{ml} / \mathrm{fed}$ mixed with mineral oil (KZ oil) at the rate of 500 $\mathrm{ml} /$ fed.

11- bispyribac-sodium $2 \%$ at the rate of $400 \mathrm{ml} / \mathrm{fed}$ mixed with spreading materials (Top film) at the rate of $1000 \mathrm{ml} / \mathrm{fed}$.

12- bispyribac-sodium $2 \%$ at the rate of $400 \mathrm{ml} / \mathrm{fed}$ mixed with spreading materials (Top film) at the rate of $500 \mathrm{ml} / \mathrm{fed}$.

13- Mineral oil (KZ oil) at the rate of $1000 \mathrm{ml} / \mathrm{fed}$.

14- Spreading materials (Top film) at the rate of 1000 $\mathrm{ml} /$ fed

15- Weedy check (control treatment).

The treatments of every experiment were arranged in complete randomized blocks. Each treatment was represented by four experimental plots of $21 \mathrm{~m} 2$. Giza 178 cultivar seeds $60 \mathrm{Kg}$ seeds/fedan, rice seeds were soaked for 24 hours in the water then incubated for 48 hours as recommended then the pre-germinated seeds were manually broadcasted in a separate nursery for each genotype at 5th and 2nd of May for first and second seasons, respectively. Such as fertilization, irrigation and insects control were applied as recommended in its certain times and rates under the recommended methodology. The post-emergence herbicide treatments were sprayed with a knapsack sprayer (cp3) at a volume rate of $2001 /$ fed.

\section{Results Recorded \\ Weed assessments:}

From each experimental plot one square meter was selected randomly, the weeds were removed from this area (one meter) after 40, 55 and 70 days from sowing. The weeds removed was identified according to Tackolm (1974). The account of number of weeds per $\mathrm{m}^{2}$ was taken for following groups:

- Narrow-leaved weeds.
- Broad-leaved weeds.

- Total of weeds.

\section{Percent control of weeds:}

The percent reduction in weed dry weight ( $\mathrm{R} \%)$ was calculated using the well-known equation.

Reduction in dry weight (\%) $=[(\mathrm{D} . \mathrm{W}$. as $\mathrm{g} / \mathrm{plant}$ in weedy check- D.W. as g/plant in treatement) / (D.W. as $\mathrm{g} /$ plant in weedy check) $\mathrm{x} 100$

\section{Weed measurements (g/m2):}

The following data were recorded on weed characters at 30, 45 and 60 days after broadcasted rice (DAB), The removed weeds which had been collected from each experimental plots each of one square meter. The dry weight of each type was recorded after 30, 45 and 60 days from sowing for each treatment (DAS). Weed characters were sampled at three times $(30,45$ and 60 days after sowing DAS, studied weed measurements as follow:

1- Number of tillers m-2 at (30,45 and 60 days after sowing DAS for every weed species in a square meter in each plot $(30,45$ and 60 days after sowing DAS).

2- Fresh and dry weight of weeds (g.m-2). Samples were air dried for two days then dried in the oven at $70 \mathrm{C} 0$ for two days or up to the stability of the weight then the average weight was recorded.

\section{Statistical Analysis:}

All obtained data were statistically analyzed using Statistical analysis (SAS) software program (2000). Data were analyzed as factorial arrangement of kind of emulsifying and storage period in complete randomized design with three replicates. Comparisons among the means of different treatments were achieved using the least significant difference procedure (LSD) at $\mathrm{P}=0.05$ and 0.01 level as illustrated by Al-Rawi and KhalafAllah (1980).

\section{RESULTS AND DISCUSSION}

Effect of tested post-emergence herbicides on the number of tiller $\left(\mathrm{m}^{-2}\right)$ and total weeds in the field during 2009 and 2010 season.

The result of table (1,2 and Fig 1 and 2) showed that the number of tiller to Echinochloa crus-galli, Echinochloa colonum, Cyperus difformis. In all tested treatment from the results the most lesser above of weeds and highest percent reduction of weeds was found in penoxsulam 2.5\% (Renpo) and bispyribacsodium 2\%. (Nominee) at the recommended rate of each herbicides wean the half rate both compounds was compared one litter of spreading material (Top film) or one litter of mineral oil (KZ oil) was slightly increased of weeds with the higher increase of percent reduction in total weeds compared with the effect of the half rate only of each tested compound. Also the results showed that the addition of zinc sulphat $(2 \%)$ was not effect. The trial attempted to reduce the hazard effect of such chemical compounds that might result from the usage of high rate as well as to reduce the cost of controlling weeds in rice plantations. 
Results of tables (2 and Fig.1,2) reveal that the addition of $1000 \mathrm{ml}$ and $500 \mathrm{ml}$ from mineral oil or $1000 \mathrm{ml}$ and $500 \mathrm{ml}$ from spreading material to penoxsulam $2.5 \%$ or bispyribac-sodium $2 \%$ at the half rate induced a significant increasing in its herbicidal activity compared with its effect at half recommended rate only specially against grassy weeds (Echinochloa crus-galli, Echinochloa colonum), broad leaved weeds (Cyperus difformis ) and totat number of tiller weeds during 30, 45 and 60 days after sowing (DAS). The penoxsulam $2.5 \%$ half rate $+1000 \mathrm{ml}$ mineral oil which gave $84 \%, 86 \%, 82 \%$ reduction in the total number of weeds during 2009 season and $85 \%, 89 \%, 82 \%$ during 2010 season. While using penoxsulam $2.5 \%$ half rate + $1000 \mathrm{ml}$ spreading material which gives $82 \%, 87 \%, 83 \%$ and $84 \%, 92 \%, 88 \%$ during 2009and 2010 season respectively. But from the other side bispyribac-sodium $2 \%$ half rate $+1000 \mathrm{ml}$ mineral oil which gave $92 \%$, $85 \%, 83 \%$ and $86 \%, 89 \%, 84 \%$. also bispyribac-sodium $2 \%$ half rate $+1000 \mathrm{ml}$ spreading material which gives $89 \%, 89 \%, 89 \%$ and $88 \%, 94 \%, 87 \%$ reduction in the total number of weeds during 2009and 2010 season respectively.

These results concerning the effects of tested postemergence herbicides on weeds infested rice plant are in the agreement results of Hussain et al. (2008), Mussavi et al. (2009) Ali et al. (2010) and Abdul Khaliq et al. (2012). They found that bispyribac-sodium $2 \%$ and penoxsulam $2.5 \%$ had been given the most higher control for weeds infested rice plant. All the above results agree with the results of Kudsk (1984), Derexler and Hindersmamn (1990), Konradt and Wulff (1990) who found that the addition of one to two litres of mineral oil to post emergence herbicides fluazifop-pbutyl proved to be an effective and economical alternative for grasses at growth stage.

Effect of tested post-emergence herbicides on dry weight $\left(\mathrm{g} \mathrm{m}^{-1}\right)$ and total weeds.

the results (Table 3,4and Fig. 3 and 4) showed the effect of tested post emergence herbicides at recommended and half recommended rate as well as its combination Penoxsulam $2.5 \%$ and Bispyribac-sodium $2 \%$ on dry weight of Echinochloa crus-galli, Echinochloa colonum, Cyperus difformis and total dry weight weeds.

The results indicated that the Penoxsulam $2.5 \%$ and Bispyribac-sodium $2 \%$ at recommended rat were gave the most highest percent reduction in total dry weight of weeds. When the mineral oil and spreading material were used with half recommended rate of the two above herbicides the percent reduction of dry weight of weed were approximately equal to the recommended rate of each tested herbicides such effect relieved to the efficacy of mineral oil and spreading material to improve the power of half rate to reach the effect of recommended rate.

Table (1): Effect of post-emergence herbicides at different rate on Number of tillers total weeds $\left(\mathrm{m}^{-2}\right)$ infested rice plants in the field during 2009 and 2010 season.

\begin{tabular}{|c|c|c|c|c|c|c|c|}
\hline \multirow{3}{*}{ Treatment } & \multirow{3}{*}{$\begin{array}{l}\text { Rate } \\
\mathrm{ml} / \text { fed }\end{array}$} & \multicolumn{3}{|c|}{2009 season } & \multicolumn{3}{|c|}{2010 season } \\
\hline & & \multicolumn{3}{|c|}{ Time (Days after sowing) } & \multicolumn{3}{|c|}{ Time (Days after sowing) } \\
\hline & & 30 & 45 & 60 & 30 & 45 & 60 \\
\hline Penoxsulam 2.5\% & 400 & $0^{\mathrm{h}}$ & $60^{\mathrm{ef}}$ & $40^{\mathrm{h}}$ & $0^{\mathrm{h}}$ & $40^{\mathrm{fg}}$ & $24^{\mathrm{h}}$ \\
\hline Penoxsulam $2.5 \%$ & 200 & $125.25^{\mathrm{bc}}$ & $296^{\mathrm{b}}$ & $412^{\mathrm{c}}$ & $128^{\mathrm{bc}}$ & $200^{\mathrm{c}}$ & $296^{\mathrm{c}}$ \\
\hline Penoxsulam $2.5 \%+$ mineral oil & $200+1000$ & $71.75^{\mathrm{ef}}$ & $136^{\mathrm{d}}$ & $172^{\mathrm{ef}}$ & $64^{\mathrm{fg}}$ & $96^{\text {def }}$ & $152^{\mathrm{fg}}$ \\
\hline Penoxsulam $2.5 \%+$ mineral oil & $200+500$ & $116^{\mathrm{c}}$ & $264^{\mathrm{bc}}$ & $394.5^{\mathrm{c}}$ & $116^{\mathrm{cd}}$ & $200^{\mathrm{c}}$ & $256^{\mathrm{cd}}$ \\
\hline Penoxsulam $2.5 \%$ + spreading material & $200+1000$ & $84^{\mathrm{de}}$ & $120^{\mathrm{d}}$ & $159^{\mathrm{fg}}$ & $68^{\mathrm{fg}}$ & $72^{\mathrm{fg}}$ & $108^{\mathrm{g}}$ \\
\hline Penoxsulam $2.5 \%$ + spreading material & $200+500$ & $144^{\mathrm{b}}$ & $314^{\mathrm{b}}$ & $413.5^{\mathrm{c}}$ & $96^{\mathrm{de}}$ & $264^{b}$ & $344^{\mathrm{b}}$ \\
\hline Bispyribac-sodium $2 \%$ & 800 & $0^{\mathrm{h}}$ & $32^{\mathrm{f}}$ & $48^{\mathrm{h}}$ & $0^{\mathrm{h}}$ & $20^{\mathrm{g}}$ & $0^{\mathrm{h}}$ \\
\hline Bispyribac-sodium $2 \%$ & 400 & $65^{\mathrm{ef}}$ & $280^{\mathrm{b}}$ & $284^{\mathrm{d}}$ & $72.5^{\mathrm{efg}}$ & $156^{\mathrm{c}}$ & $220^{\text {de }}$ \\
\hline Bispyribac-sodium $2 \%+$ mineral oil & $400+1000$ & $36^{\mathrm{g}}$ & $143^{\mathrm{d}}$ & $163.5^{\mathrm{fg}}$ & $60^{\mathrm{g}}$ & $92^{\mathrm{ef}}$ & $142^{\mathrm{g}}$ \\
\hline Bispyribac-sodium $2 \%+$ mineral oil & $400+500$ & $88^{\text {de }}$ & $208^{\mathrm{c}}$ & $224^{\mathrm{e}}$ & $68^{\mathrm{fg}}$ & $150.25^{\mathrm{cd}}$ & $216^{\mathrm{de}}$ \\
\hline Bispyribac-sodium $2 \%+$ spreading material & $400+1000$ & $52^{\mathrm{fg}}$ & $108^{\mathrm{de}}$ & $107^{\mathrm{g}}$ & $53.5^{\mathrm{g}}$ & $48^{\mathrm{fg}}$ & $112^{\mathrm{g}}$ \\
\hline Bispyribac-sodium $2 \%+$ spreading material & $400+500$ & $66^{\mathrm{fe}}$ & $272^{\mathrm{b}}$ & $304^{\mathrm{d}}$ & $72^{\text {efg }}$ & $146.5^{\text {cde }}$ & $188^{\mathrm{ef}}$ \\
\hline Mineral oil & 1000 & $446^{\mathrm{a}}$ & $926^{\mathrm{a}}$ & $948.75^{\mathrm{a}}$ & $418^{\mathrm{a}}$ & $842^{\mathrm{a}}$ & $852^{\mathrm{a}}$ \\
\hline Spreading material & 1000 & $446^{\mathrm{a}}$ & $924^{\mathrm{a}}$ & $944^{\mathrm{a}}$ & $414^{\mathrm{a}}$ & $737^{\mathrm{a}}$ & $848^{\mathrm{a}}$ \\
\hline Weedy check & - & $456^{\mathrm{a}}$ & $944^{\mathrm{a}}$ & $952^{\mathrm{a}}$ & $428^{\mathrm{a}}$ & $854.5^{\mathrm{a}}$ & $868^{\mathrm{a}}$ \\
\hline F.test & - & $* *$ & $* *$ & $* *$ & $* *$ & $* *$ & $* *$ \\
\hline
\end{tabular}

Means of each factor within each column, values flowed by the same letters are not significantly different at 5\% level, using Duncans Multiple Range test. 
Also Ferrero (1999) found that when mineral oil was added to clethodim, it could improve the control of red rice grasses up to $95 \%$. These results concerning the effects of tested post- emergence herbicides on weeds infested rice plant are in the agreement results of (Hassan et al., Ghansham and Surjit, 2008), (Kogan et al., Mahajana and Timsinab, 2011), Rashid et al. (2012). found that bispyribac-sodium $2 \%$ and penoxsulam $2.5 \%$ was the effectively and economically controlling weeds and improving the productivity of rice. Also the compound more significantly reduced the total weed population and weed dry matter production resulting in higher weed control efficiency as compared to weedy check. From these results it is suggested that the addition of mineral oil to the tested post-emergence herbicides could improve their adsorption and the translocation through wax layer of grassy weed and then trans located successfully with in symplastic system of weeds to induce the potential power of its activity. This suggestion is proposed due to the known effect of oil on destroying the semi permeable living membranes, by solubilization the interpolation of oil molecules into the protein layer of the membrane with loss of bonding, diconfiguration and leakage as stated by Van Overbeek and Blondeau (1954), Crafts and Robbin (1962).

Table (2): Percent reduction on total Number of tillers weeds $\left(\mathrm{m}^{-2}\right)$ infested rice plants in the field during 2009 and 2010 season.

\begin{tabular}{|c|c|c|c|c|c|c|c|}
\hline \multirow{4}{*}{ Treatment } & \multirow{4}{*}{$\begin{array}{c}\text { Rate } \\
\mathrm{ml} / \text { fed }\end{array}$} & \multicolumn{3}{|c|}{2009 season } & \multicolumn{3}{|c|}{2010 season } \\
\hline & & \multicolumn{3}{|c|}{ Time (Days after sowing) } & \multicolumn{3}{|c|}{ Time (Days after sowing) } \\
\hline & & \multicolumn{6}{|c|}{ Percent reduction on total Number of tillers (\%) } \\
\hline & & 30 & 45 & 60 & 30 & 45 & 60 \\
\hline Penoxsulam 2.5\% & 400 & $100 \%$ & $94 \%$ & $96 \%$ & $100 \%$ & $95 \%$ & $97 \%$ \\
\hline Penoxsulam $2.5 \%$ & 200 & $73 \%$ & $69 \%$ & $57 \%$ & $70 \%$ & $77 \%$ & $66 \%$ \\
\hline Penoxsulam $2.5 \%+$ mineral oil & $200+1000$ & $84 \%$ & $86 \%$ & $82 \%$ & $85 \%$ & $89 \%$ & $82 \%$ \\
\hline Penoxsulam $2.5 \%+$ mineral oil & $200+500$ & $75 \%$ & $72 \%$ & $59 \%$ & $73 \%$ & $77 \%$ & $71 \%$ \\
\hline Penoxsulam $2.5 \%$ + spreading material & $200+1000$ & $82 \%$ & $87 \%$ & $83 \%$ & $84 \%$ & $92 \%$ & $88 \%$ \\
\hline Penoxsulam $2.5 \%$ + spreading material & $200+500$ & $68 \%$ & $67 \%$ & $57 \%$ & $78 \%$ & $69 \%$ & $60 \%$ \\
\hline Bispyribac-sodium $2 \%$ & 800 & $100 \%$ & $97 \%$ & $95 \%$ & $100 \%$ & $98 \%$ & $100 \%$ \\
\hline Bispyribac-sodium $2 \%$ & 400 & $86 \%$ & $70 \%$ & $70 \%$ & $83 \%$ & $82 \%$ & $75 \%$ \\
\hline Bispyribac-sodium $2 \%+$ mineral oil & $400+1000$ & $92 \%$ & $85 \%$ & $83 \%$ & $86 \%$ & $89 \%$ & $84 \%$ \\
\hline Bispyribac-sodium 2\%+ mineral oil & $400+500$ & $81 \%$ & $78 \%$ & $76 \%$ & $84 \%$ & $82 \%$ & $75 \%$ \\
\hline Bispyribac-sodium $2 \%+$ spreading material & $400+1000$ & $89 \%$ & $89 \%$ & $89 \%$ & $88 \%$ & $94 \%$ & $87 \%$ \\
\hline Bispyribac-sodium $2 \%+$ spreading material & $400+500$ & $86 \%$ & $71 \%$ & $68 \%$ & $83 \%$ & $83 \%$ & $78 \%$ \\
\hline Mineral oil & 1000 & $2 \%$ & $2 \%$ & $0 \%$ & $2 \%$ & $1 \%$ & $2 \%$ \\
\hline Spreading material & 1000 & $2 \%$ & $2 \%$ & $1 \%$ & $3 \%$ & $14 \%$ & $2 \%$ \\
\hline Weedy check & - & $0 \%$ & $0 \%$ & $0 \%$ & $0 \%$ & $0 \%$ & $0 \%$ \\
\hline
\end{tabular}

Percent reduction of total number $=\left(\right.$ No. Of teller total weeds $/ \mathrm{m}^{2}$ in weedy checks - No. Of teller total weeds $/ \mathrm{m}^{2}$ in treatment $) /$ No. Of teller total weeds $/ \mathrm{m}^{2}$ as in weedy check

Table (3): Effect of post-emergence herbicides at different rate on total dry weight of weeds $\left(\mathrm{g} . \mathrm{m}^{-1}\right)$ for infested rice plants in the field during 2009 and 2010 season.

\begin{tabular}{|c|c|c|c|c|c|c|c|}
\hline \multirow{3}{*}{ Treatment } & \multirow{3}{*}{$\begin{array}{c}\text { Rate } \\
\mathrm{ml} / \text { fed }\end{array}$} & \multicolumn{3}{|c|}{2009 season } & \multicolumn{3}{|c|}{2010 season } \\
\hline & & \multicolumn{3}{|c|}{ Time (Days after sowing) } & \multicolumn{3}{|c|}{ Time (Days after sowing) } \\
\hline & & 30 & 45 & 60 & 30 & 45 & 60 \\
\hline Penoxsulam $2.5 \%$ & 400 & $0^{\mathrm{g}}$ & $10.57^{1}$ & $185.68^{\mathrm{e}}$ & $0^{\mathrm{g}}$ & $7.92^{\mathrm{f}}$ & $5.92^{\mathrm{gh}}$ \\
\hline Penoxsulam $2.5 \%$ & 200 & $21.02^{\mathrm{bc}}$ & $122.58^{\mathrm{d}}$ & $301.58^{\mathrm{d}}$ & $18.49^{\mathrm{cd}}$ & $82.85^{\mathrm{cd}}$ & $144.88^{\mathrm{bcd}}$ \\
\hline Penoxsulam $2.5 \%+$ mineral oil & $200+1000$ & $12.01^{\mathrm{def}}$ & $43.76^{\mathrm{gh}}$ & $136.72^{\mathrm{ef}}$ & $10.81^{\mathrm{ef}}$ & $32.82^{\mathrm{ef}}$ & $94.32^{\mathrm{ef}}$ \\
\hline Penoxsulam $2.5 \%$ + mineral oil & $\mathbf{2 0 0}+500$ & $15.41^{\mathrm{b}-\mathrm{e}}$ & $110.91^{\mathrm{de}}$ & $274.00^{\mathrm{d}}$ & $17.36^{\mathrm{cd}}$ & $71.97^{\mathrm{cd}}$ & $102.90^{\text {de }}$ \\
\hline Penoxsulam $2.5 \%$ + spreading material & $200+1000$ & $18.92^{\text {bcd }}$ & $36.39^{\mathrm{h}}$ & $132.28^{\mathrm{ef}}$ & $9.21^{\mathrm{f}}$ & $15.00^{\mathrm{f}}$ & $49.25^{\mathrm{fg}}$ \\
\hline Penoxsulam $2.5 \%$ + spreading material & $\mathbf{2 0 0}+500$ & $22.55^{\mathrm{b}}$ & $148.32^{\mathrm{c}}$ & $309.64^{\mathrm{d}}$ & $16.06^{\mathrm{d}}$ & $88.24^{\mathrm{c}}$ & $161.38^{\mathrm{bc}}$ \\
\hline Bispyribac-sodium 2\% & 800 & $0^{\mathrm{g}}$ & $6.90^{\mathrm{i}}$ & $15.37^{\mathrm{g}}$ & $0^{\mathrm{g}}$ & $2.85^{\mathrm{f}}$ & $0^{\mathrm{h}}$ \\
\hline Bispyribac-sodium 2\% & 400 & $9.96^{\mathrm{ef}}$ & $93.57^{\mathrm{ef}}$ & $184.35^{\mathrm{e}}$ & $6.64^{\mathrm{f}}$ & $62.00^{\mathrm{cd}}$ & $89.39^{\text {ef }}$ \\
\hline Bispyribac-sodium $2 \%+$ mineral oil & $400+1000$ & $5.04^{\mathrm{fg}}$ & $60.49^{g}$ & $96.16^{\mathrm{f}}$ & $9.37^{\mathrm{f}}$ & $27.45^{\mathrm{ef}}$ & $51.50^{\mathrm{fg}}$ \\
\hline Bispyribac-sodium $2 \%+$ mineral oil & $400+500$ & $15.01^{\text {cde }}$ & $89.09^{\mathrm{f}}$ & $142.08^{\text {ef }}$ & $11.17^{\mathrm{ef}}$ & $62.34^{\mathrm{cd}}$ & $122.24^{\text {cde }}$ \\
\hline Bispyribac-sodium $2 \%+$ spreading material & $400+1000$ & $5.41^{\mathrm{fg}}$ & $36.16^{\mathrm{h}}$ & $74.49^{\mathrm{fg}}$ & $6.95^{\mathrm{f}}$ & $11.50^{\mathrm{f}}$ & $33.21^{\mathrm{gh}}$ \\
\hline Bispyribac-sodium $2 \%+$ spreading material & $400+500$ & $10.03^{\text {ef }}$ & $113.46^{\mathrm{de}}$ & $182.32^{\mathrm{e}}$ & $9.58^{\mathrm{f}}$ & $27.03^{\mathrm{ef}}$ & $92.85^{\mathrm{ef}}$ \\
\hline Mineral oil & 1000 & $104.0^{\mathrm{a}}$ & $670.0^{\mathrm{a}}$ & $981.47^{\mathrm{a}}$ & $82.00^{\mathrm{a}}$ & $496.0^{\mathrm{a}}$ & $712.00^{\mathrm{a}}$ \\
\hline Spreading material & 1000 & $102.13^{\mathrm{a}}$ & $680 . .19^{\mathrm{a}}$ & $971.38^{\mathrm{a}}$ & $85.87^{\mathrm{a}}$ & $521.70^{\mathrm{a}}$ & $721.16^{\mathrm{a}}$ \\
\hline Weedy check & - & $110.94^{\mathrm{a}}$ & $694.20^{\mathrm{a}}$ & $983.98^{\mathrm{a}}$ & $89.27^{\mathrm{a}}$ & $572.13^{\mathrm{a}}$ & $730.09^{\mathrm{a}}$ \\
\hline F.test & - & $* *$ & $* *$ & $* *$ & $* *$ & $* *$ & $* *$ \\
\hline
\end{tabular}

Means of each factor within each column, values flowed by the same letters are not significantly different at 5\% level, using Duncans Multiple Range test. 


\section{Echinochloa crus-galli $=$ Echinochloa colonum $=$ Cyperus difformis}

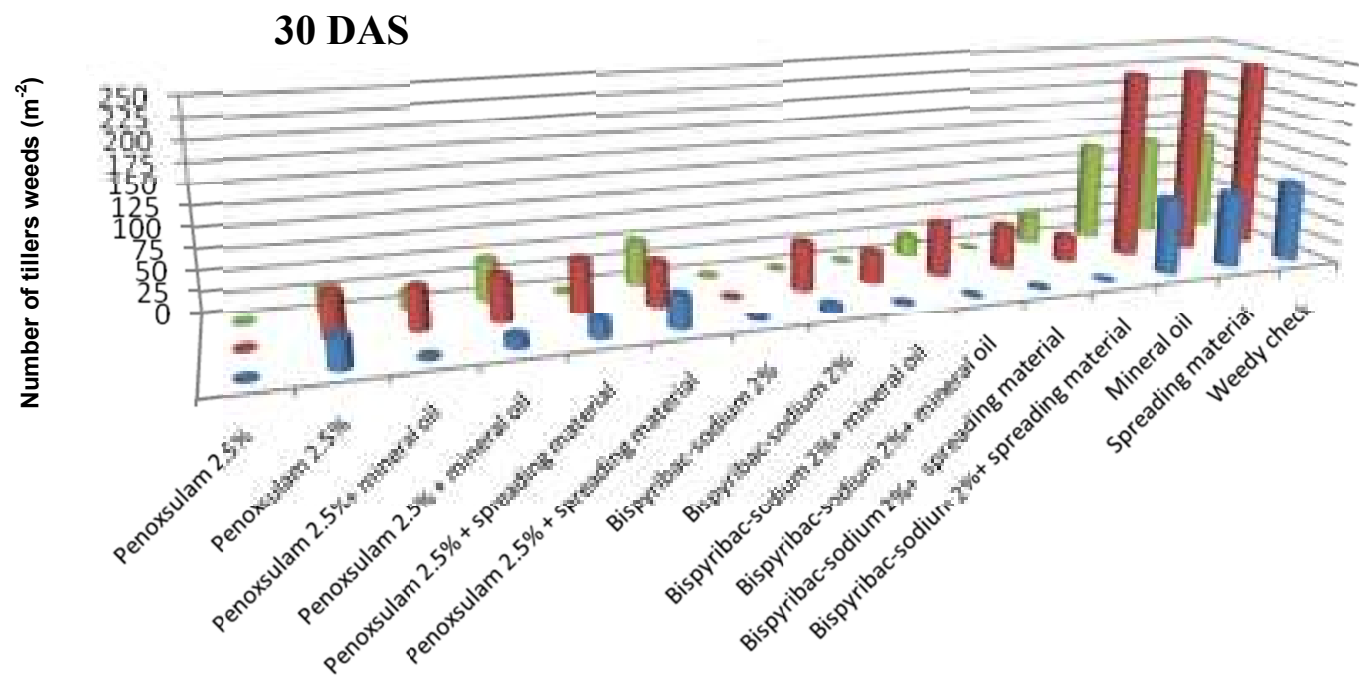

Treatment

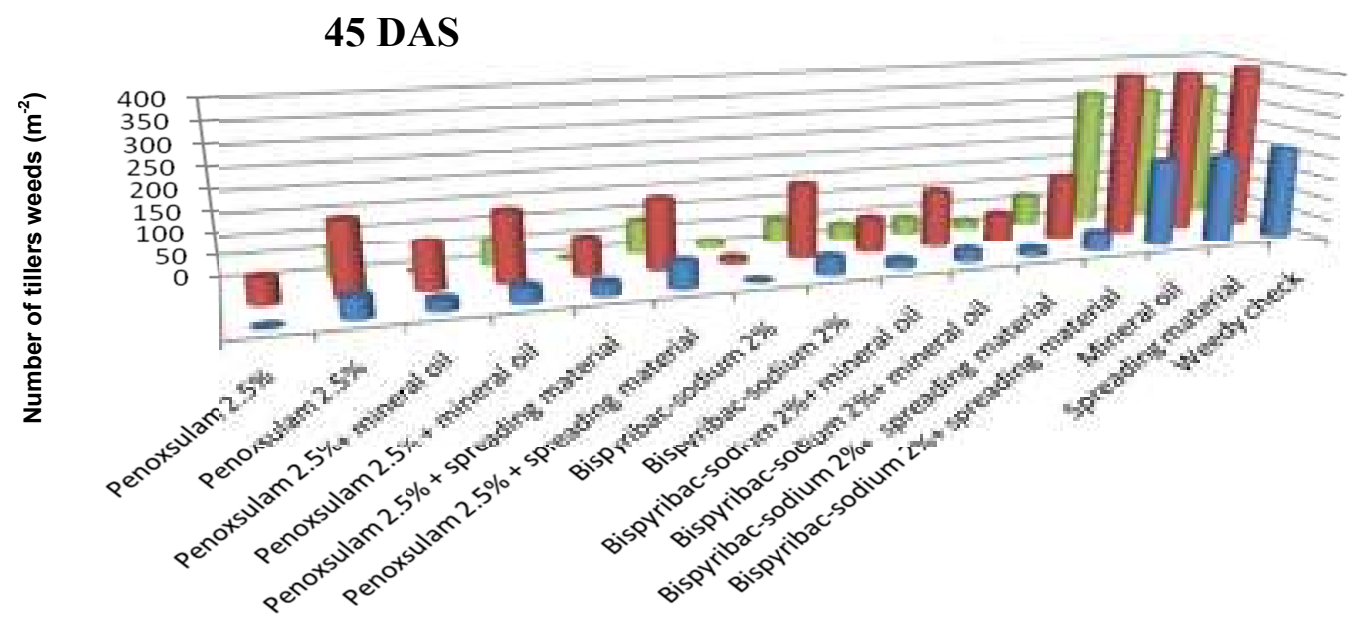

Treatment

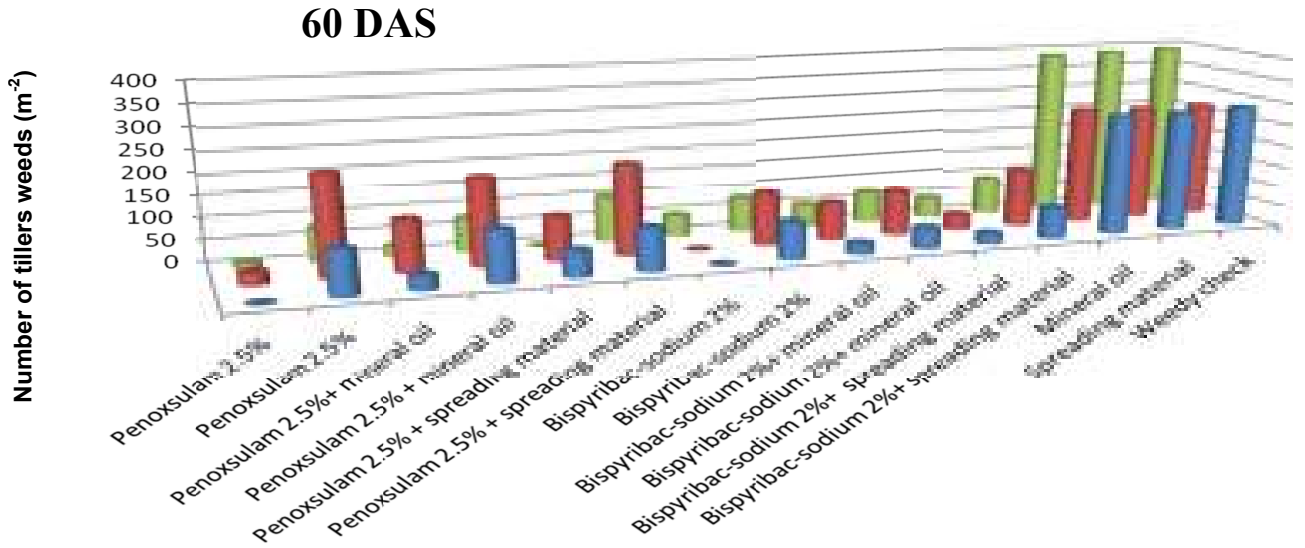

Treatment

Fig. (1): Effect of post-emergence herbicides at different rate on Number of tillers $\left(\mathrm{m}^{-2}\right)$ for Echinochloa crus-galli, Echinochloa colonum and Cyperus difformis infested rice plants at 30, 45 and 60 days after sowing in the field during 2009. 


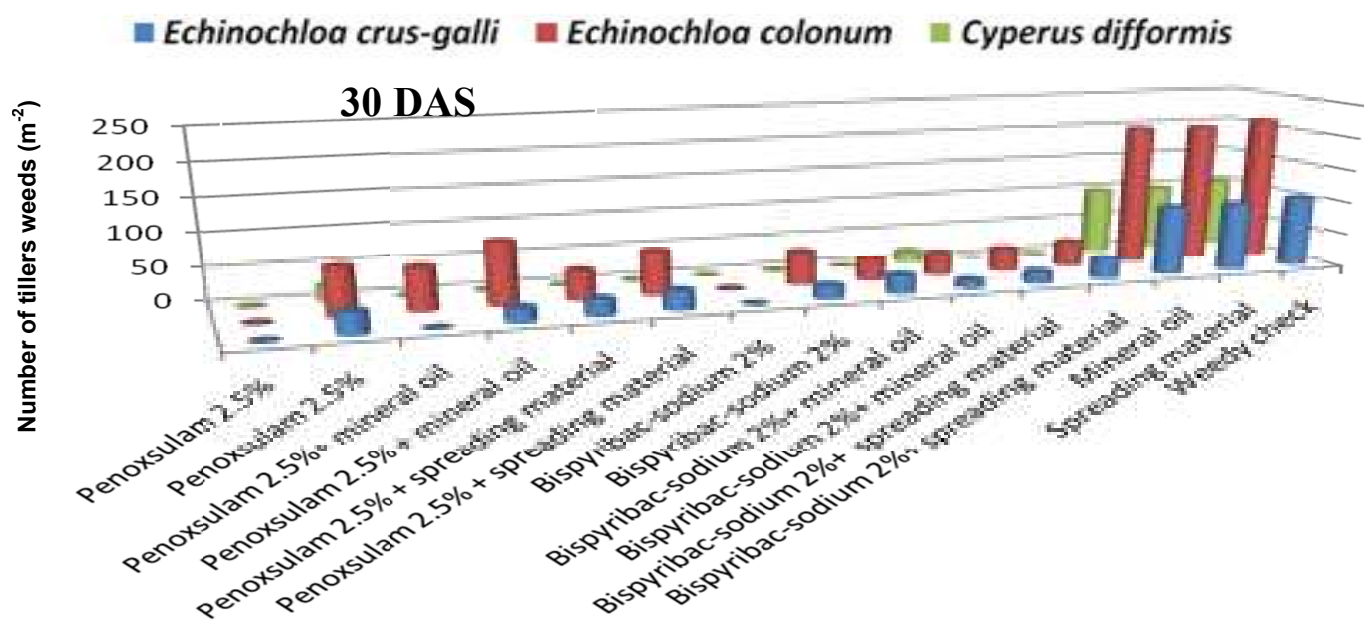

Treatment

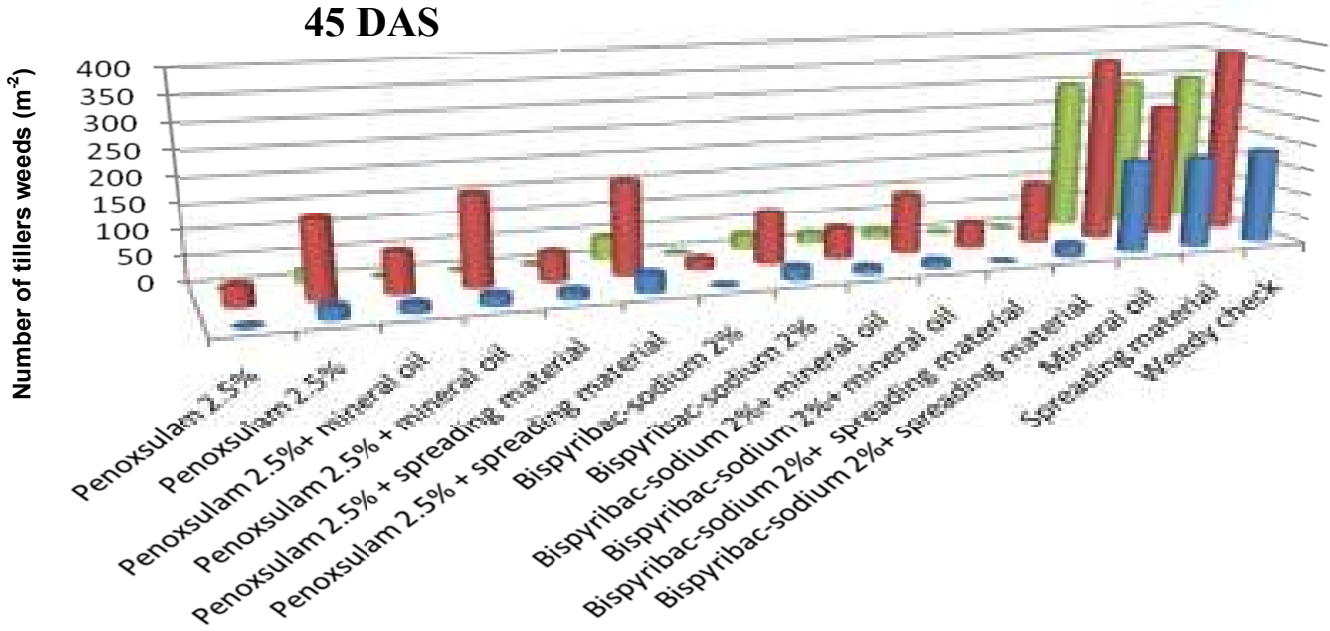

Treatment

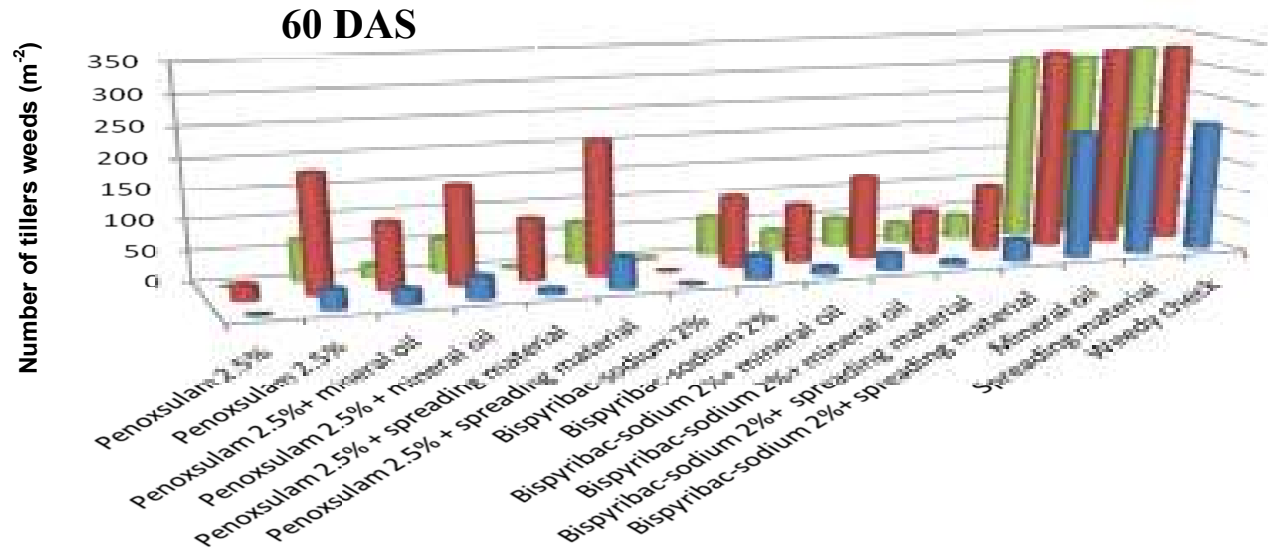

\section{Treatment}

Fig. (2): Effect of post-emergence herbicides at different rate on Number of tillers $\left(\mathrm{m}^{-2}\right)$ for Echinochloa crus-galli, Echinochloa colonum and Cyperus difformis infested rice plants at 30,45 and 60 days after sowing in the field during 2010. 


\section{Echinochloa crus-galli Echinochloa colonum $\|$ Cyperus difformis}

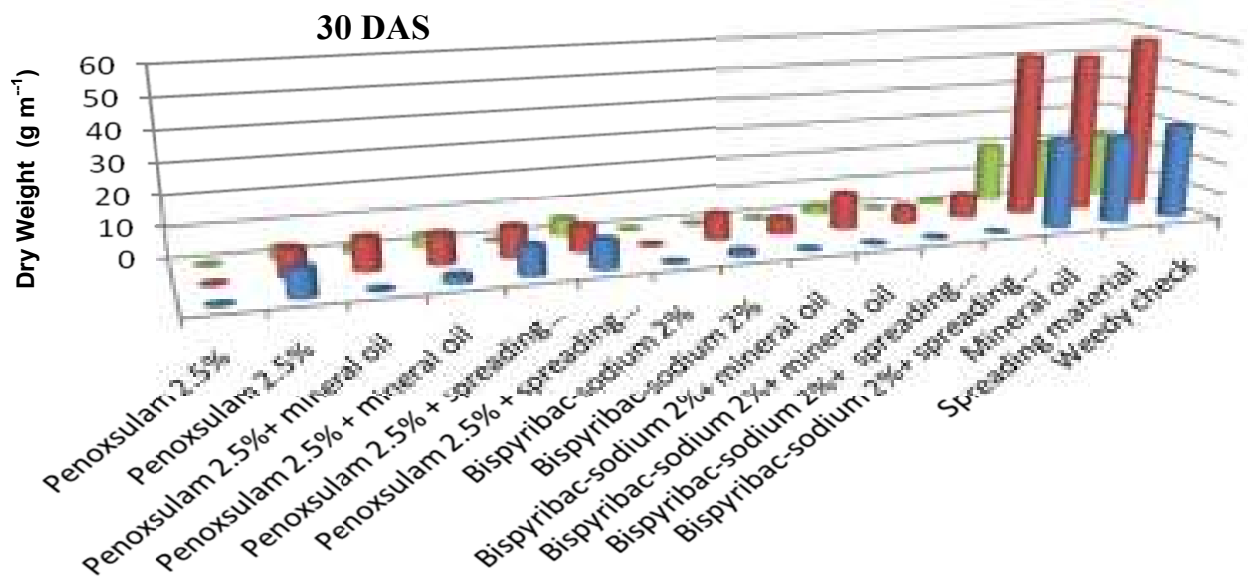

Treatment

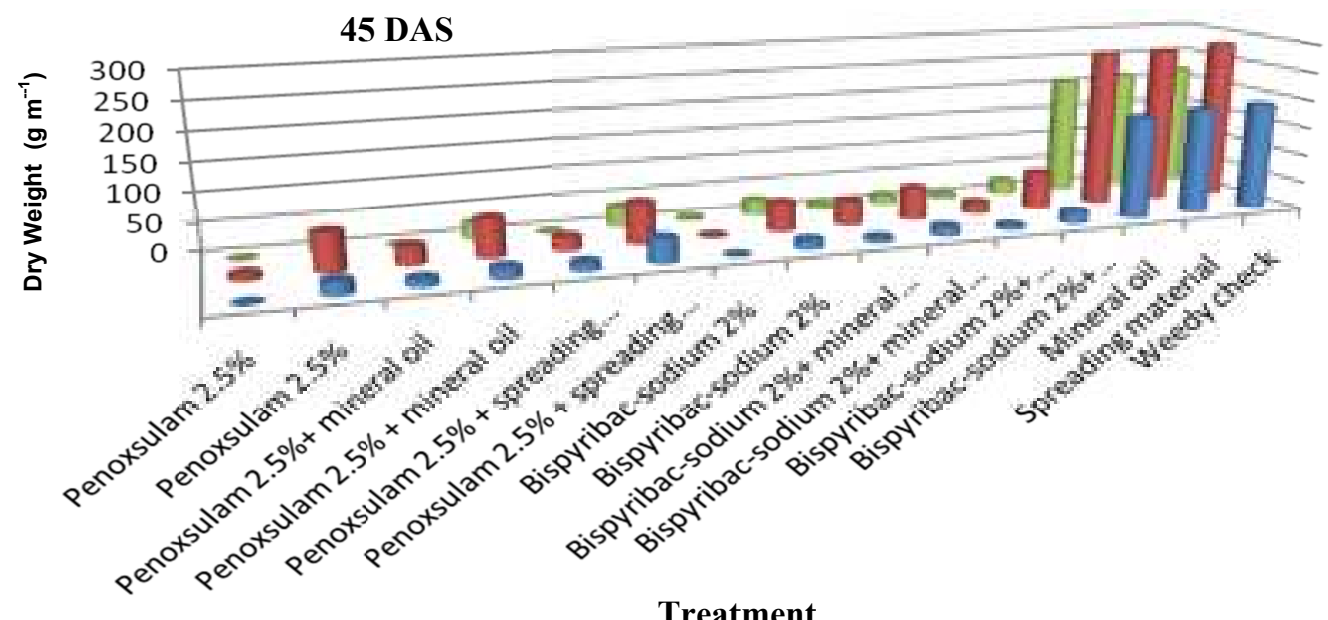

Treatment

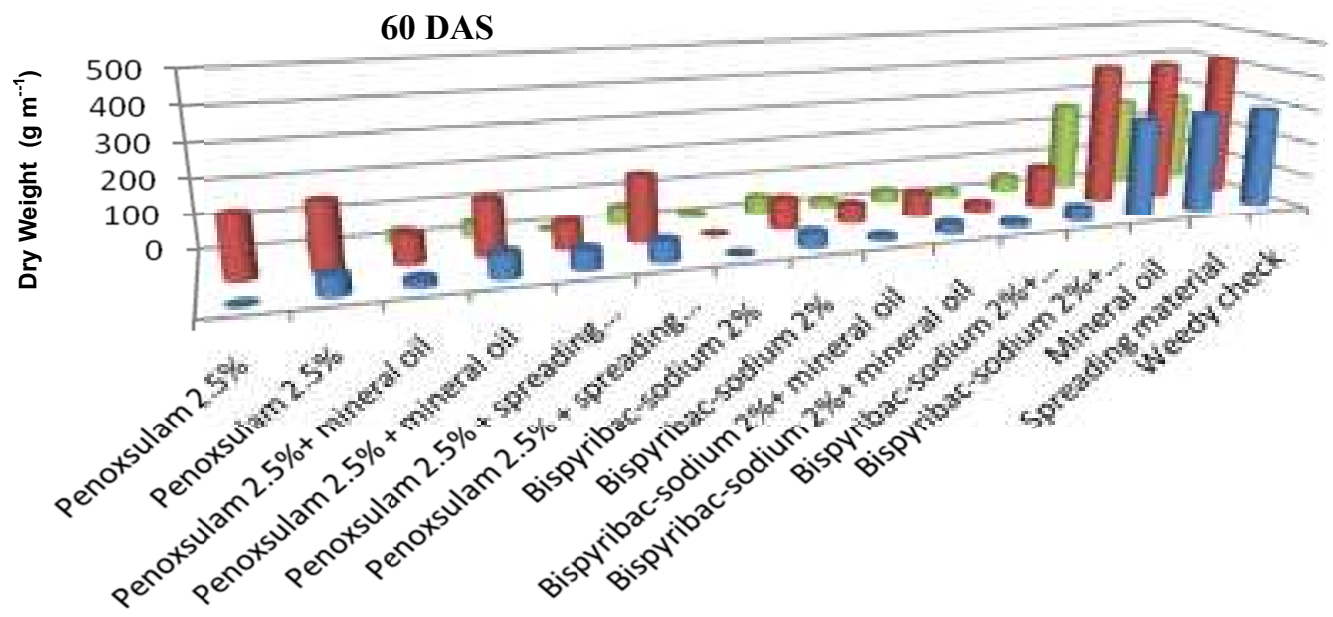

Treatment

Fig. (3): Effect of post-emergence herbicides at different rate on dry weight $\left(\mathrm{g} \mathrm{m}^{-1}\right)$ for Echinochloa crus-galli, Echinochloa colonum and Cyperus difformis infested rice plants at 30, 45 and 60 days after sowing in the field during 2009. 


\section{Echinochloa crus-galli $\|$ Echinochloa colonum $\|$ Cyperus difformis}

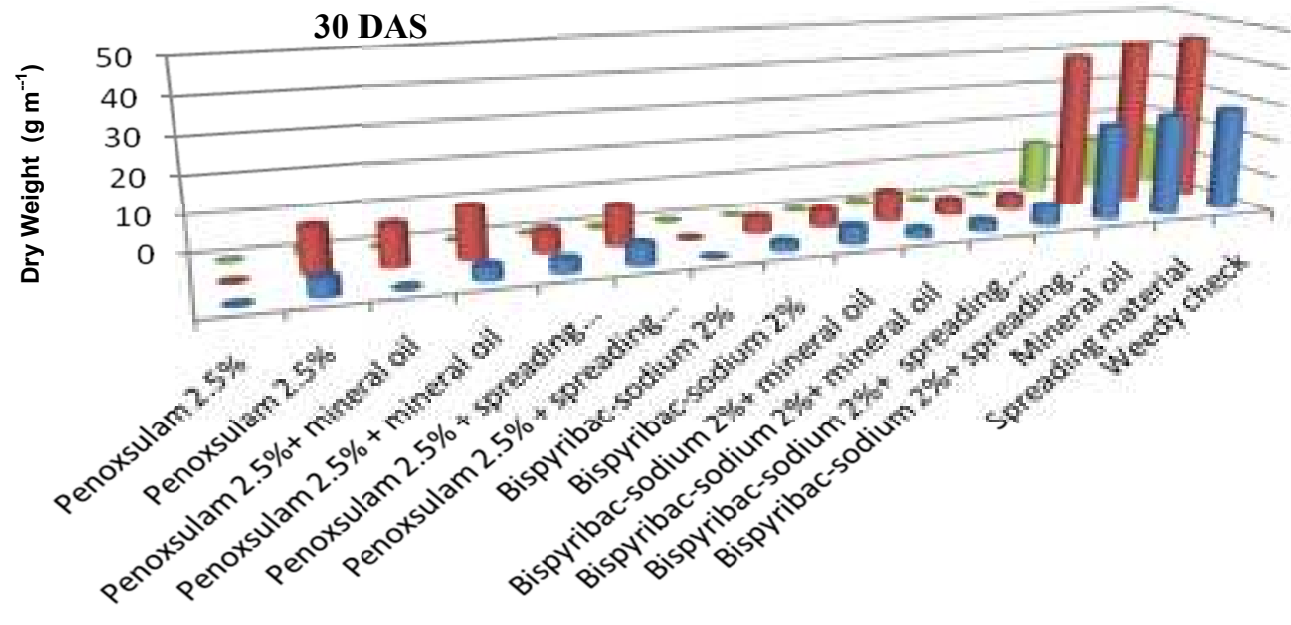

Treatment

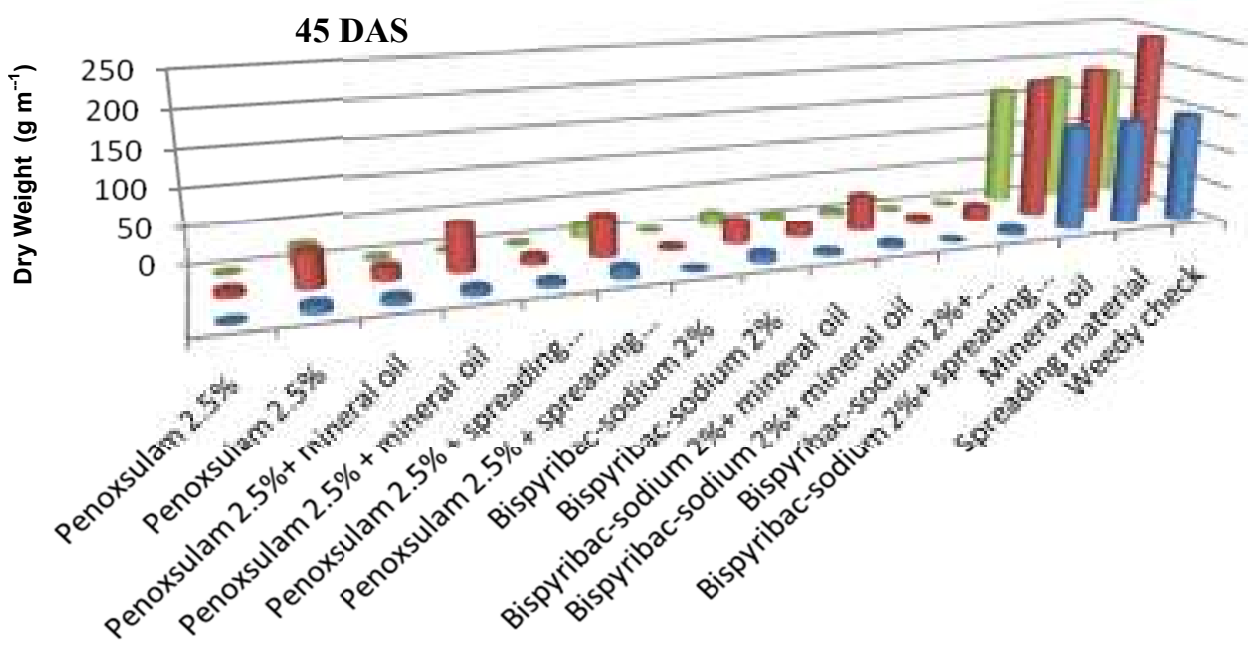

Treatment

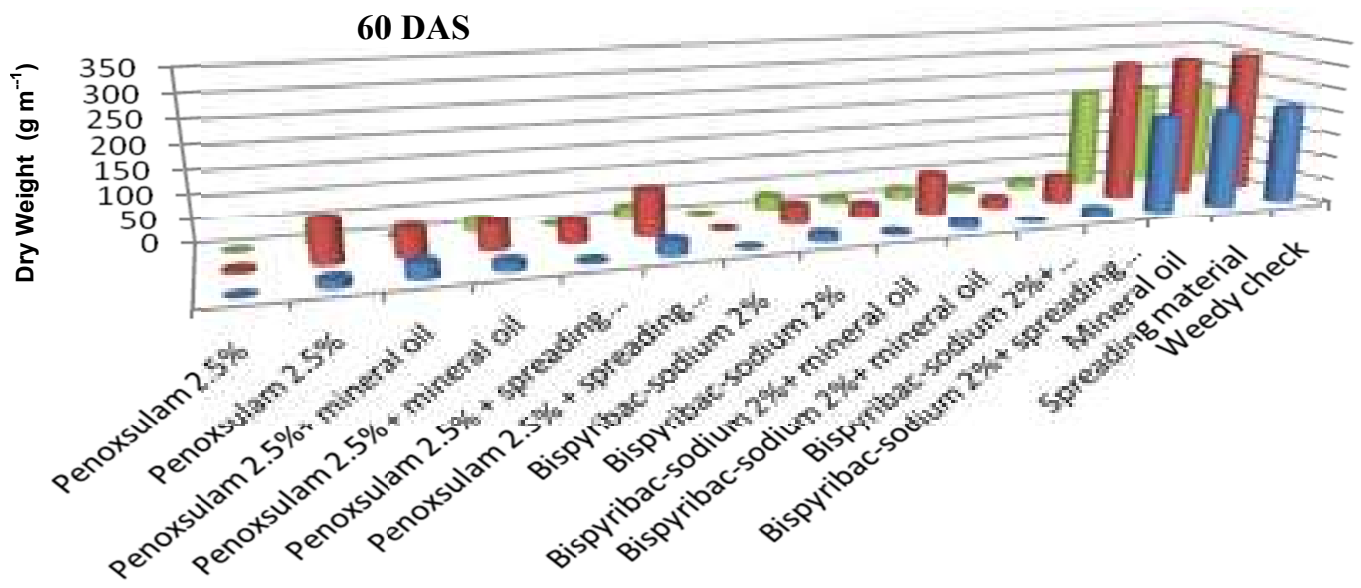

Treatment

Fig. (4): Effect of post-emergence herbicides at different rate on dry weight $\left(\mathrm{g} \mathrm{m}^{-1}\right)$ for Echinochloa crus-galli, Echinochloa colonum and Cyperus difformis infested rice plants at 30, 45 and 60 days after sowing in the field during 2010. 
Table (4): Percent reduction on total dry weight of weeds $\left(\mathrm{g} \cdot \mathrm{m}^{-1}\right)$ for infested rice plants in the field during 2009 and 2010 season.

\begin{tabular}{|c|c|c|c|c|c|c|c|}
\hline \multirow{4}{*}{ Treatment } & \multirow{4}{*}{$\begin{array}{c}\text { Rate } \\
\mathrm{ml} / \text { fed }\end{array}$} & \multicolumn{3}{|c|}{2009 season } & \multicolumn{3}{|c|}{2010 season } \\
\hline & & \multicolumn{3}{|c|}{ Time (Days after sowing) } & \multicolumn{3}{|c|}{ Time (Days after sowing) } \\
\hline & & \multicolumn{6}{|c|}{ Percent reduction on total dry weight of weeds (\%) } \\
\hline & & 30 & 45 & 60 & 30 & 45 & 60 \\
\hline Penoxsulam 2.5\% & 400 & $100 \%$ & $98 \%$ & $81 \%$ & $100 \%$ & $99 \%$ & $99 \%$ \\
\hline Penoxsulam $2.5 \%$ & 200 & $81 \%$ & $82 \%$ & $69 \%$ & $79 \%$ & $86 \%$ & $80 \%$ \\
\hline Penoxsulam $2.5 \%+$ mineral oil & $200+1000$ & $89 \%$ & $94 \%$ & $86 \%$ & $88 \%$ & $94 \%$ & $87 \%$ \\
\hline Penoxsulam $2.5 \%+$ mineral oil & $200+500$ & $86 \%$ & $84 \%$ & $72 \%$ & $81 \%$ & $87 \%$ & $86 \%$ \\
\hline Penoxsulam $2.5 \%$ + spreading material & $200+1000$ & $83 \%$ & $95 \%$ & $87 \%$ & $90 \%$ & $97 \%$ & $93 \%$ \\
\hline Penoxsulam $2.5 \%$ + spreading material & $\mathbf{2 0 0}+\mathbf{5 0 0}$ & $80 \%$ & $79 \%$ & $69 \%$ & $82 \%$ & $85 \%$ & $78 \%$ \\
\hline Bispyribac-sodium 2\% & 800 & $100 \%$ & $99 \%$ & $98 \%$ & $100 \%$ & $100 \%$ & $100 \%$ \\
\hline Bispyribac-sodium 2\% & 400 & $91 \%$ & $87 \%$ & $81 \%$ & $93 \%$ & $89 \%$ & $88 \%$ \\
\hline Bispyribac-sodium $2 \%+$ mineral oil & $400+1000$ & $95 \%$ & $91 \%$ & $90 \%$ & $90 \%$ & $95 \%$ & $93 \%$ \\
\hline Bispyribac-sodium 2\%+ mineral oil & $400+500$ & $86 \%$ & $87 \%$ & $86 \%$ & $87 \%$ & $89 \%$ & $83 \%$ \\
\hline Bispyribac-sodium $2 \%+$ spreading material & $400+1000$ & $95 \%$ & $95 \%$ & $92 \%$ & $92 \%$ & $98 \%$ & $95 \%$ \\
\hline Bispyribac-sodium $2 \%+$ spreading material & $400+500$ & $91 \%$ & $84 \%$ & $81 \%$ & $89 \%$ & $95 \%$ & $87 \%$ \\
\hline Mineral oil & 1000 & $6 \%$ & $3 \%$ & $0 \%$ & $8 \%$ & $13 \%$ & $2 \%$ \\
\hline Spreading material & 1000 & $8 \%$ & $2 \%$ & $1 \%$ & $4 \%$ & $9 \%$ & $1 \%$ \\
\hline Weedy check & - & $0 \%$ & $0 \%$ & $0 \%$ & $0 \%$ & $0 \%$ & $0 \%$ \\
\hline
\end{tabular}

Percent reduction of total dry weight $=\left(\right.$ Total dry weight weeds $/ \mathrm{m}^{2}$ in weedy checks - Total dry weight weeds $/ \mathrm{m}^{2}$ in treatment $) /$ Total dry weight weeds $/ \mathrm{m}^{2}$ asin weedly check

\begin{tabular}{ll}
\hline & \multicolumn{1}{c}{ Abbreviation used } \\
\hline PRE & Pre-emergence Herbicide \\
POST & Post-emergence Herbicide \\
WAS & Week After Sowing \\
WAP & Week After Planting \\
WAE & Week After Emergence \\
DW & Dry Weight \\
DAP & Days After Planting \\
No & Number \\
PPI & Pre- Plant Incorporated \\
DAB & Days After Planting \\
DAS & Days After Sowing \\
\hline
\end{tabular}

\section{REFERENCES}

Abdul Khaliq; A. Matloob; S. Mahmood; R. N. Abbas and M. B. Khan (2012). Seeding density and herbicide tank mixtures furnish better weed control and improve growth, yield and quality of direct seeded fine rice. International Journal of Agriculture \& Biology, 14 (4): 499-508.

Abdul khaliq; M.Y. Riaz and A.Matloob (2011). Bioeconomic assessment of chemical and nonchemical weed management strategies in dry seeded fine rice (Oryza sativa L.). Journal of Plant Breeding and Crop Science, 3(12):302-310.

Ali, Md.H.; H.M.M.T. Hossain and S. Ahamed (2010). Growth and yield of hybrid and inbred boro rice affected by different methods of weed control. Pak. J. Weed Sci. Res., 16(2):169-180.

Al-Rawy, K. M. and A. M. Khalf-Allah (1980). Design and Analysis of Agriculture Experimental. Text book. El-Mousil Univ. press Ninawa, Iraq. 487.pp.
Crafts A.S. and Robbins W.W. (1962). Weed control, a Text book and Manual. McGraw-Hill Book co., New York. 660 pp.

De Datta, S. K. (1980). Weed control in rice in South and Southeast Asia. Food and Fret. Tec. Center Ext. Bull. 156. Taipei City, Taiwan, 24P.

Drexler G. and Hindersmamu U. (1990). Recent findings for grass control in potatoes Kartoffelbau. 41, 157-159.

Ferrero A., Vidotto F., Balsari P., and Airoldi G. (1999). Mechanical and chemical control of red rice (Oryza sativa L. var. sylvatica) in rice (Oryza sativa L.) pre-planting. Crop-Protection. 18, 245 251.

Ghansham, P. and S. Surjit (2008). Effect of seeded rat, spacing and herbicide use on weed management in direct seeded upland rice (Oryza sativa L.). Indian Journal of Weed Science, Volume :40, Issue:1-2.

Hassan, S. M. (2002). Weed management in rice. Rice in Egypt book, pages: 164-197.

Hassan, S. M. and A. N. Rao (1994). Weed impact analysis and management for sustainable production in irrigated rice in Egypt. 45th EWRS Mediterranean Symposium "Weed Control in Sustainable Agriculture in the Mediterranean area", Perugia, 261-268.

Hassan, S. M.; S. M. Shebl and I. H. Abou El- Darag (2008). Performance of new herbicides application in drill-seeded rice. 4th Conf. ElFayoum, Egypt. 20-22- October, pp.13-24.

Hassan, S.M. and S.M. Shebl (2004). Integrated Allelopathy and herbicides in weed management in direct-seeded rice. Proc. The International Conf. on Advanced Rice Res. Alex., Egypt, 2123 Sept., pp. 33. 
Hussain, S.; M. Ramzan; M. Akhter and M. Aslam (2008). Weed management in direct seeded rice. J. Anim. PI. 0Sci. (18):2-3.

Jabran, K.; Ehsanullah; M. Hussain; M. Farooq; M. Babar; M, Nedin and Dong-Jin Lee (2012). Application of bispyribac-sodium provides effective weed control in direct-planted rice on a sandy loam soil. Weed Biology and Management, (12):136-145.

Kogan, M.; P. Gomez; A. Fischer and C. Alister (2011). Using penoxsulam ALS inhibitor as a broadspectrum herbicide in Chilean rice. Ciencia investigacion Agraria 38(1): 83-93.

Konradt M.W. and Wulff G. (1990). Fusilade new strategy for beet. Zuckerrube. 39, 81-84.

Kudsk P. (1984). A method for determining the influence of additives on herbicides performance. 1-Danske plant vaernskonference, Ukrudt. 178195.

Mahajan, G. and J. Timsina (2011). Effect of nitrogen rates and weed control methods on weeds abundance and yield of direct-seeded rice. Archives of Agronomy and Soil Science, 57(3):239-250.

Mussavi, S. H.; Kh. Alamisaied; Gh. Fathi; M. H. Gharineh; M. R. Moradi-Telavat and A. Siahpoosh (2009). Optimum rice density and herbicide application in direct seeding in Ahwaz region, Iran. Asian Journal of Crop Science 1(1): 58-62.
Rao A.S. and M. Ratnam (2010). Evaluation of post emergence herbicides on weed control in rice nursery. Pak. J. weed sci. Res., 16(4):387-392.

Rashid, M. H.; M. M. Alam; A. N. Rao and J. K. Ladha (2012). Comparative efficacy of pretilachlor and hand weeding in managing weeds and improving the productivity and net income of wet-seeded rice in Bangladesh. Field Crop Research (128), 17-26.

Smith, R. J. Jr.; W. T. Flinchum and D. E. Seaman (1977). Weed control in U. S. rice production. U. S. Dep. Agric. Handb. 497. U. S. Gov. Printing Office, Washington. D. C. 78P.

Statistical analysis, SAS Institute. (2000). SAS User's Guide, Version 4.02 . SAS Inst., CARY, N.C.

Tackholm V. (1974). Student's Flora of Egypt. 2nd Ed. Cairo Univ., Egypt. Graphical Service, Beirut, Lebanon.

Taylor, M. C. and W. S. Clampett (2002). Developing weed management strategies to achieve effective weed control in rice in New South Wales, Australia. Pages 603-614 in Proceedings of the 2nd Temperate Rice Conference. ed. by Hill, J. E. and B. Hardy. International Rice Research Institute, P. O. Box 933. Manila, Philippines.

Van Overbeek J. and Blondeau R. (1954). Mode of action of phototoxic oil. weeds. 3, 55-65.

Wally, Y. A. (1989). Rice Farming System - New Directions. Proceedings of an International Symposium, 31 Jan.-3 Feb. 1987, Rice Research and Training Center, Sakha, Egypt. 